\title{
BEGINNINGS, CONDITIONS AND PERSPECTIVES OF TOURISM IN THE CITY OF SHTIP
}

\section{Nikola V. Dimitrov", Simona Atanasova}

${ }^{1}$ Faculty of Tourism and Business Logistics - Gevgelia, University "Goce Delchev" - Shtip;

${ }^{2}$ Faculty of Tourism and Business Logistics - Shtip, University "Goce Delchev" - Shtip; nikola.dimitrov@ugd.edu.mk, simona.atanasova93@yahoo.com

\section{Professional Paper doi:10.5937/jouproman6-16562}

\begin{abstract}
For a scientists is a challenger to explore the beginning and the course of tourism in smaller cities. The emergence of tourism in Shtip is from a recent date. However, through the example of tourism in Shtip, we identify two historical periods: the preturism and the period of tourism. Thus, the first period lasts until the appearance of the first hotel in 1912, and the second from the middle of the twenties of the 20th century.Serious data on the tourism in Shtip are obtained from the end of the 1950 's onwards. The analysis is based on primary and secondary data sources. From the analysis we learn that the tourism in Shtip in recent years has been growing with real development perspectives of diverse tourist offer and production.
\end{abstract}

Keywords: history of tourism, periods, karavasaray, anovi, hotels, restaurants, perspectives, Shtip, Republic of Macedonia

\section{Introduction}

City of Stip is the largest city in the eastern part of the Republic of Macedonia (RM).

The city is located between the heights of the hills of Isar ( $450 \mathrm{~m}$ above sea level), Merite (420 $\mathrm{m}$ above sea level) and Cumlacot (peak Klisse Bair $591 \mathrm{~m}$ above sea level), and extends along the two the bank of the river Otinja $(3 \mathrm{~km})$ and the river Bregalnica $(3 \mathrm{~km})$. The area of the town of Shtip is $13,5 \mathrm{~km}^{2}$, altitude $300 \mathrm{~m}$, altitude of Isar $450 \mathrm{~m}$. length of the city north - south $6 \mathrm{~km}$, the width of the city east - west $6 \mathrm{~km}$.

The city's is divided into about 20 urban communities. In the city there is Banja Kezovica $59^{\circ} \mathrm{C}$ and another warm spring Lchi. The city has 47,796 inhabitants, 4 primary and 5 secondary schools, a university with 15 faculties, etc.

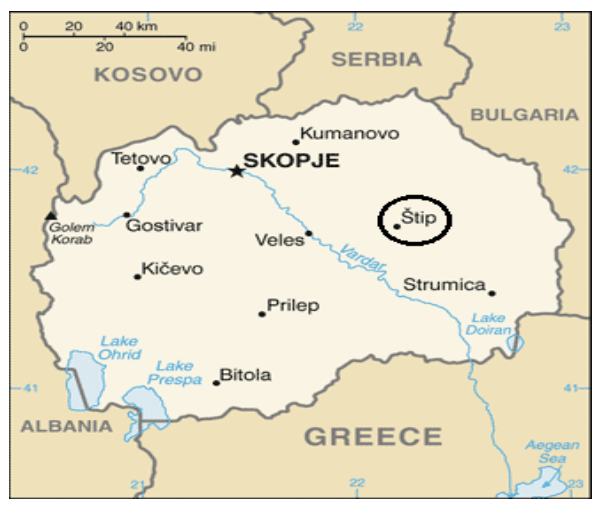

Figure 1. Geographical location of Shtip in the Republic of Macedonia

Shtip is the seat of the Municipality (with $893 \mathrm{~km}^{2}$ with 48 settlements) and the seat of the East Planning Region $\left(3,537 \mathrm{~km}^{2}\right.$, $14 \%$ of the territory of the RM with over 181,000 inhabitants $10 \%$ of the RM, with a density of $51 \mathrm{~km} / \mathrm{km}^{2}$ and in which they 11 gravitate municipalities, with a total of 217 settlements).(Dimitrov, V. N., Joseski, D., Miteva, N. (2017).

\section{Methodology}

The research uses a qualitative analysis based on the review and examination of relevant primary (archival documents and published books) and secondary sources (statistical data, historical and contemporary written sources, as well as scientific publications, but also a questionnaire and interview). 
The main unit of measure for tourism development are tourist arrivals, but for pre-tourism or prototourism for which we do not have data as the basic measure are the number of anovi, caravansaras and hotels that most often received guests travelers (traders, foreign travelers and others). The data group the first period covers caravansarians and anovi from the 15 th century to the present, while for hotels it covers the period from 1912 onwards.

We are investigating the number of tourists from the period when they were registered for Shtip, and that is from 1958 onward, because for the previous period we did not find data for tourists in the city.

\section{Results of the survey}

In general, for the city of Shtip, we group the results in two periods with several subperiods. This is supported by the following arguments. The first period is in front of the tourist and covers the subperiod when the Republic of Macedonia and Shtip are under the Ottoman rule, then the sub-period of the Balkan and World War I, and ends with the sub-period when the Republic of Macedonia and Shtip are part of the Vardar Banovina, ie under the rule of the Kingdom of Yugoslavia (19191941), in this sub-period we include the Second World War (1941-1944).

For the whole of this period, only for certain years we are able to find data on the number of caravansarays, anovi, hotels and menas, but nowhere is the number of guests or tourists mentioned. That means there is still no beginning of tourism.

After the Second World War, the period of tourism begins. We divide the period of tourism into two sub-periods, and this subperiod when the Republic of Macedonia and Shtip are part of the SFR Yugoslavia (1945-1991) and sub-period from 1991 onwards, that is, from the independence of the Republic of Macedonia.

First quantitative data for catering facilities, tourists and overnight stays for Shtip, which means for the tourist period, we meet in 1958. Since then, the tourism in Shtip has seen various cycles of rising and falling.

\section{Beginnings and states}

The predecessors of the hotels in Macedonia and wider in the Ottoman Empire were caravansarai and anovi.

In the travelogue of Hadzi Kalfa Mustafa from around 1650, he noticed that there is one large caravan - Saraj in Istip (Shtip). The same was confirmed by the traveler Evliya Celebija in 1661, who wrote that in Shtip there was a double decker caravansarai with 50 rooms on the floor and seven anovi. There were seven anovi in the city, the most famous of which were "Sinan-Begov An", "Kara-Kadini An", "Chumulji Zade An". The other anovi were: "Kuchuk-Emir-An", "Elmazov-An", "Pirinchan-An", "Alikiov An" and "AnlarIlinde-An". (Aleksova, B., Apostolski, M.,1986; Matkovski, A., 2002;Dimitrov, V. N. \& Veljanov, T., 2017)

In 1883, 12 anovi and one café were built in Shtip and 32 anovi were restored. In some of them there were also fountains. From the end of the XIX century until 1912 in Shtip there were a total of 47 anovi for the overnight stay of the merchants and marketers who came by merchandise in the city. Among them were: Pirini an Akifaa an, Mamudov an, Toshanski an, Zoev an (Zavovoev), Azhipetsov an, Dukov an, Danov an, Goritsa an, Miladin an, Teransky an, Azhikostadinov an and others. Matkovski, A., 2002;Dimitrov, V. N. \& Veljanov, T., 2017)

The first hotel built in Shtip is "Grand Hotel" (owned by the church municipality). It was probably built in the period 19101912.Other two hotels were the hotel "Solun - Thessaloniki" owned by Vane Filipov Paunche and hotel "Balkan" by Goco Postolo. For these two hotels, it is not determined when they appear, but most probably their existence is in the period 1913-1918, ie during the military actions. 
In the early thirties in Stip the first mountaineering association "Bregalnica" was formed. (Stojmilov, A., 1993; Stojmilov, A. \& Tosevska A B., 2016; Panov, N., 1996).

In the period 1919-1941, the number of hotels in Shtip was as follows: in 1926 4 hotels were registered, in 19365 hotels, and in 19398 hotels. Some of the hotels were former inns and with renovation and adaptation they became hotels. They worked with interruptions and often changed their name. From our analysis, in the period 1916-1939 we managed to identify the names of 12 hotels, which does not mean that everyone worked the entire period, hotel "Kruna", hotel "King Serbian king or King Alexander", hotel "Avala", "Grand hotel - later Novi Beograd", hotel "Solun - Thessaloniki", hotel "Balkan", "Savin hotel later"Bregalnica "Hotel Proleke", hotel" Moscow ", hotel" Culture ", hotel" Jagoda ", and hotel" Lepi izgled ". In most of these hotels there were restaurants and cafes.

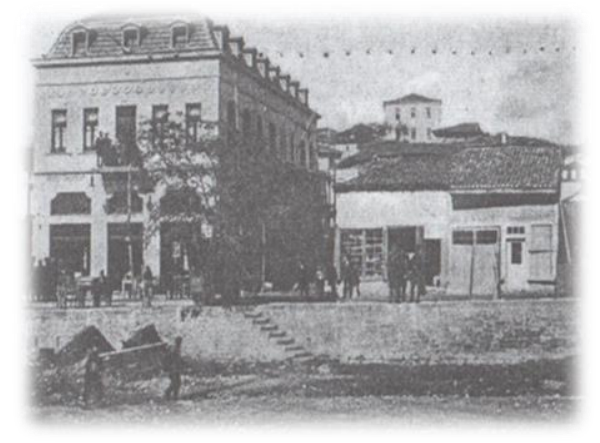

Figure2. Hotel "Kring" in 1930

Despite the large number of hotels, in Shtip, the then Royal State Statistics, the city does not mention it as a tourist place, so we do not have data on tourists. (GSS, 1929-1940).

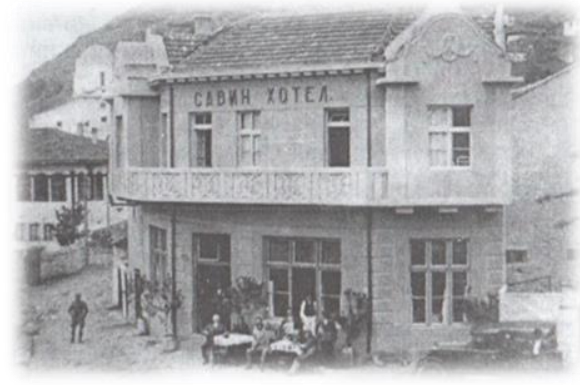

Figure3. "Savin hotel"

Famous cafes and krchma were: "Brioni", "Shumadia", "Spring", "Pirinch han", "Zvezda", "Bregalnica", "Lepi izgled", "Zaharieva", "Zajkova", "Oslobodjenje" "The Choche", the krchma "Bunker", the krchma "Solun Thessaloniki" and others.

Also, during the Second World War and in about ten years after it, we were unable to find out the flows of the number of tourists in the city.

After the Second World War the period of tourism begins. The first data for a number of tourists in Shtip is since 1958 when 5577 tourists were registered (of which only 155 were foreign), which had 12434 overnight stays (of which 155 foreign). In that year, there were 15 catering establishments in the city and only 30 beds. This means that most of the hotels were nationalized and stopped working. With the construction of the hotel "Astibo" in 1974, the conditions of catering and tourism are improving considerably. Thus, in 1982 in Shtip there were 54 business units, 206 beds, 14270 tourists registered (out of which 467 foreign), who made 28579 overnight stays (out of which 885 foreign).

The highest number of visitors in Shtip was in 1984 with 15967 tourists registered, who had 28057 overnight stays. (See Table 1, Figure 5 and 6)

In 1996, we registered the lowest data on the number of tourists and overnights, including 2984 tourists and 4275 nights. 
The situation with the tourism from 2010 continues to improve significantly, so in 2016 there are 80 catering business units in the city of Stip, 220 beds, a visit of 6714 tourists (out of which 3667 foreign with participation in the total number of 54.6\%), who realized 15244 nights (out of which 9056 foreign with a share of $59.4 \%$ ) with an average of 2.2 days (SSO, 1958, 1982, 1996, 2016).

From Table 1, Figure 5 and 6, it is noticeable that the largest increase in the number of tourists is registered with foreign tourists and overnight stays. Namely, foreign tourists from 155 in 1958 increased to 3667 in 2016, an increase of 3512 tourists, or $2265 \%$ or about 23 times. An even higher increase is recorded in overnight stays realized by foreign tourists, from 155 in 1958 to 9056 overnights in 2016, which is an increase of 8901 overnights, $5742 \%$ or 57 times.

These figures speak of a rise in tourism. Particularly increased among foreign tourists who usually come for hunting, visiting and participating in cultural and other events organized by the city, and less for visiting the Kezhovica spa. However, the expansion of the number of foreign tourists has been since 2007, ie since the establishment of the University "Goce Delchev" (UGD) with its seat in Shtip.

Namely, since then, the number of foreign tourists visiting and staying in Shtip has significantly increased. A large number of foreign professors, students and other persons come to the University and its faculties for the purpose of staying in or participating in scientific and expert conferences, symposiums and other forms of cooperation organized by UGD.

Tourists, Shtip visit him because of significant natural and anthropogenic attractive motifs. For tourists it is quite attractive that the city's location is located on several hills and between two rivers, as well as the bath with poplar springs.
The cultural and historical monuments distributed throughout the city, dating from the ancient period onwards, are also attractive. Tourists visit the ancient medieval Fortress "Isar", and are also visited by churches that are old from the 14th century onward (St. Spas, St. Nicholas, St. Mary, St. Basil, St. John the Baptist, St. Dimitrija), then the medieval clock tower, the Bezisten, the mosque, the city museum, the several memorial houses, the national theater, the home of culture and other monuments.

In Shtip throughout the year there are more cultural entertainment ("Mak Fest") and gastronomic manifestations ("Pastrmalija"), which are visited by domestic and foreign tourists. All this, confirms that the city has opportunities and prospects for tourism promotion.

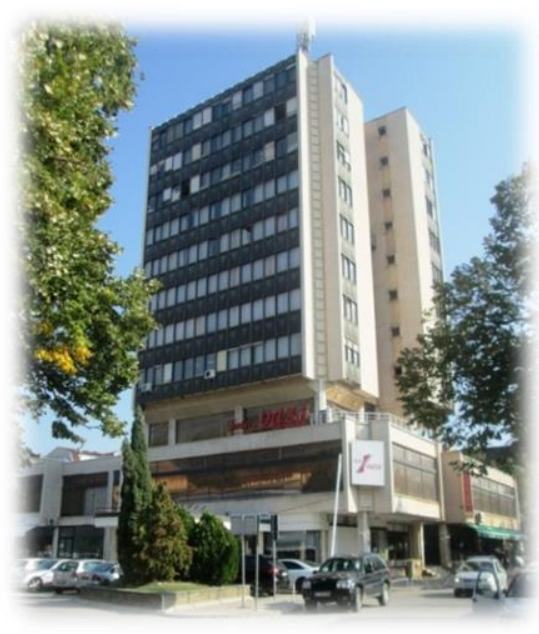

Figure 4. Hotel "Oaza”

Today, in the city of Stip, there are 12 hotels, motels, villas and apartments: "Oaza" (renovated in 2001 with 60 beds), "Izgrev" (built in 1987 with 28 beds), Petrol Hotel "Vago" 1990 with 55 beds), Motel Vago 2 - Krupiste, hotel Garni (9 beds), hotel "Kim", hotel Radio Cafe Kanal 77 "(6 beds), motel" Citkus "" Urbanist - Boutique hotel "," Short Term Apartments "," Grande NVP "and Villa" Mag Exclusive ". 
There are 8 tourist agencies as well as 60 catering facilities in the tourism industry: 25 restaurants ("Longourov", "Small Holiday", "Necko", "Aleks", "Necko 2", "Mehana za Merak" "Merak", "Sofra", "Krusevo", "Chardak", "University Club", etc.), 7 pizzerias ("Verona", "Alberta", "San Remo", "Roma", etc.) taverns, 11 fast food restaurants, 4 dairy restaurants and a dozen other facilities.(Dimitrov, V. N., Joseski, D., Miteva, N. (2017).

In the city there are also several private student dormitories ("Hilyadnikov", "Danilov" and others), accommodating students, and in the summer period tourists.

(Dimitrov, N. V., Metodijevski, D. (2017)

Table 1: Number of tourists and nights in Shtip, from 1958 to 2016

\begin{tabular}{|c|c|c|c|c|c|c|c|}
\hline \multirow{3}{*}{ Years } & \multirow{3}{*}{$\begin{array}{c}\text { Number } \\
\text { of stores } \\
-\end{array}$} & \multirow{3}{*}{$\begin{array}{c}\text { Number } \\
\text { of beds }\end{array}$} & \multicolumn{2}{|c|}{ Number of tourists } & \multicolumn{2}{|c|}{ Number of nights } & \multirow{3}{*}{$\begin{array}{c}\text { Average } \\
\text { in days }\end{array}$} \\
\hline & & & \multirow{2}{*}{ Total } & Of that: & \multirow{2}{*}{ Total } & Of that: & \\
\hline & & & & Foreign & & Foreign & \\
\hline 1958 & 15 & 30 & 5577 & 155 & 12434 & 155 & 2,2 \\
\hline 1968 & 50 & 69 & 6645 & 287 & 11492 & 710 & 1,7 \\
\hline 1982 & 54 & 206 & 14270 & 467 & 28579 & 885 & 2,0 \\
\hline 1983 & 61 & 206 & 13167 & 400 & 23287 & 820 & 1,7 \\
\hline 1984 & 63 & 186 & 15967 & 1806 & 28057 & 4261 & 1,7 \\
\hline 1985 & 62 & 186 & 14261 & 1314 & 23565 & 2223 & 1,6 \\
\hline 1986 & 69 & 186 & 12173 & 864 & 23812 & 2132 & 1,9 \\
\hline 1994 & 53 & 202 & 3748 & 1607 & 7037 & 2781 & 1,8 \\
\hline 1996 & 32 & 192 & 2984 & 965 & 4275 & 1781 & 1,4 \\
\hline 2000 & 40 & 192 & 2349 & 951 & 4283 & 1878 & 1,8 \\
\hline 2005 & 45 & 210 & 4449 & 1554 & 8300 & 3273 & 1,8 \\
\hline 2008 & 52 & 210 & 7399 & 2541 & 17425 & 5673 & 2,3 \\
\hline 2010 & 63 & 200 & 5795 & 2600 & 12463 & 6174 & 2,1 \\
\hline 2011 & 70 & 180 & 6770 & 3353 & 14776 & 8619 & 2,1 \\
\hline 2016 & 80 & 220 & 6714 & 3667 & 15244 & 9056 & 2,2 \\
\hline
\end{tabular}

Source: Statistical Yearbook of SRM and RM, from 1958 to 2016 
(JPMNT) Journal of Process Management - New Technologies, International Vol. 6, No 2, 2018.

Figure 5. Number of tourists in Shtip, 1958-2016

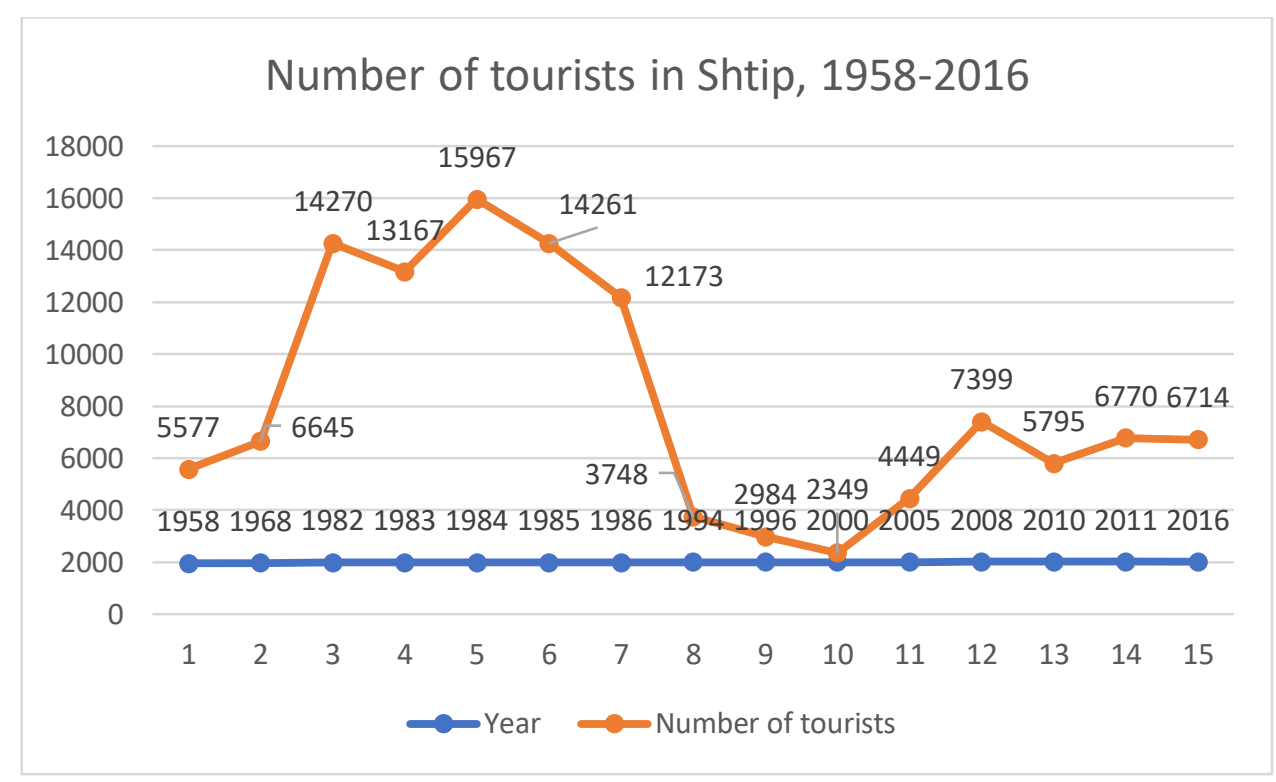

Figure 6. Number of night in Shtip, 1958-2016

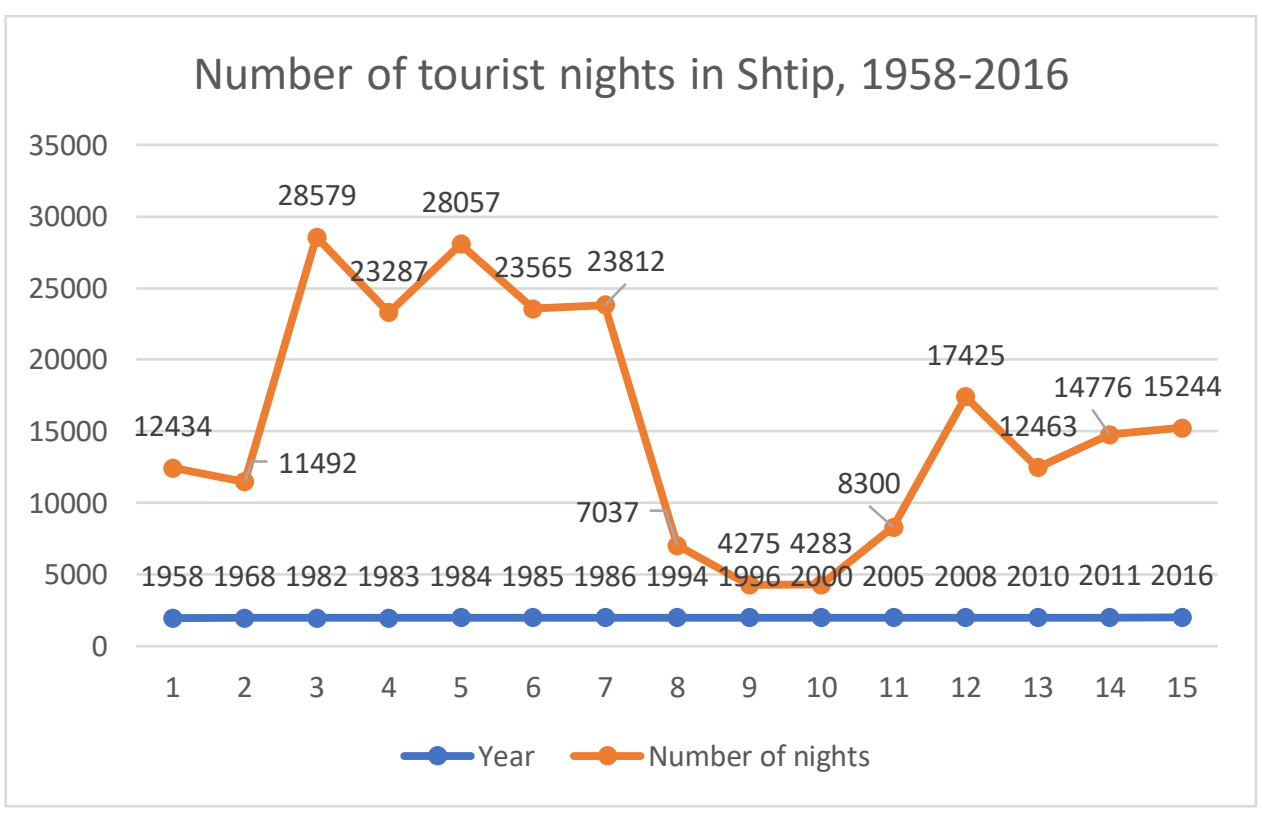




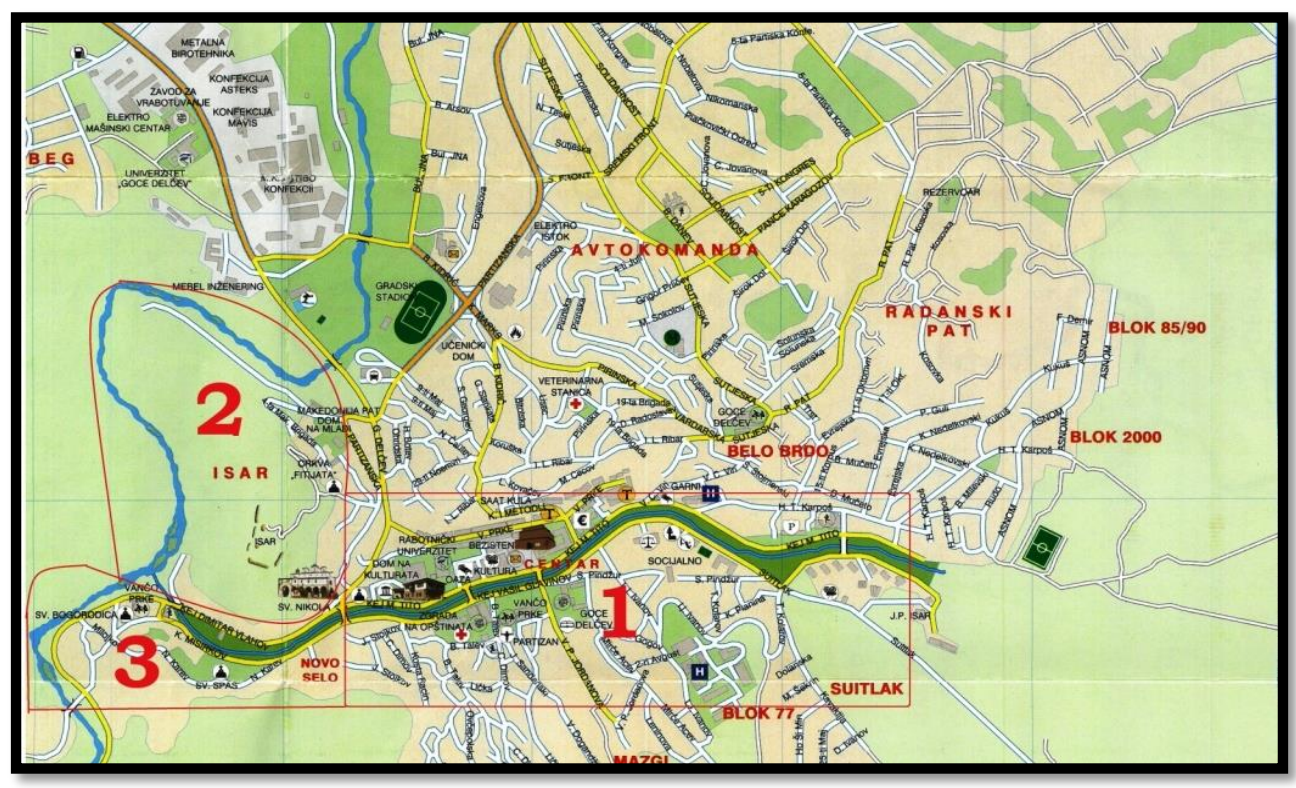

Figure 7. Tourist zones in the town of Shtip

\section{Perspectives}

To develop tourism in Shtip, significant investments are needed, enriched offer of new contents, promotion, construction of hotels with 4 and 5 stars, elite restaurants, Spa center "Kezhovica", arrangement of the archeological site "Isar" with the construction of Museum of open Fortress Isar, construction of Ethno Museum "Novo Selo", establishment of tourist info center, promotion of new tourist contents and so on.

In Shtip there is enough content for sightseeing of the city. From the analysis, we distinguish three zones that in the near future can function as touristic routes in the consideration of the city. We propose the following tourist zones: zone of central city area, zone "Isar", and zone Novo Selo with Banja Kezhovica. (See Figure 7)

\section{Conclusion}

Generally, Shtip has less influence over the entire tourist period than the cities in the Republic of Macedonia (Ohrid, Skopje, Struga, Dojran, Bitola, Gevgelijaand Prilep) which are considerably ahead. This is primarily caused by the economic conditions, poor tourist infrastructure and insufficient promotion and neglect for the development of tourism in the city of Shtip.

The local community and the region need to develop a Strategy for tourism development in the city of Shtip.

Shtip has perspectives for economic development and strengthening of the role of a regional tourist center. It is realistically possible that Shtip becomes a tourist attraction Spa and an urban cultural and historical destination with a diverse offer of more events throughout the year.

\section{References}

1.Matkovski, A. (1991). Macedonia in the works of foreign writers 1371-1777 (pp. 878). Skopje. (in Macedonian)

2.Matkovski, A. (2002). Macedonia in the works of foreign writers 1879-1888 (pp. 348). Skopje (in Macedonian)

3.Dimitrov, V. N. \& Veljanov, T. (2017). Form anovi to hotels \& from meana to restaurants, Shtip, pp.123 (in Macedonian)

4.Aleksova, B., Apostolski, M. (1986). Shtip through the centuries. Assembly of the Municipality of Shtip.(in Macedonian)

5. GSS. Statistical yearbook 1929, 1930, 1931, 1932, 1933, 1934-1935, 1936, 1937, 1938-1939, 1940. 
Kingdom of Yugoslav, General State Statistics, Book 110, Beograd. (in Serbian)

6. State Statistical Ofice of the Republic of Macedonia (SSO). Statistical yearbook for SFRJ, PRM, SRM, 1956, 1961, 1962, 1966, 1971, 1976, 1981, 1986, 1988, Skopje (in Macedonian)

7. SSO. Statistical yearbook for Republic of Macedonia, 1991, 1992, 1998, 2001, 2006, 2011, 2016, Skopje (in Macedonian)

8.Stojmilov, A., (1993) Tourism geography, Skopje(in Macedonian)

9. Dimitrov, V. N., Joseski, D., Miteva, N. (2017). Spatial and regional perspectives of Stip and expected tourist implications. Proceedings from the second international scientific-expert conference: Conditions and perspectives in tourism, economics and business logistics. University "Goce Delcev", Stip, 253 - 272.(in Macedonian)
10.Panov, N. (1996) Tourism Development in the Republic of Macedonia, Proceedings and Congress of the Geographers of R. Macedonia, 2628.X.1995, Ohrid,Skopje, pp. 311-321 (in Macedonian)

11. Stojmilov, A. \& Tosevska A B. (2016). Socioeconomic Geography of the Republic of Macedonia, Skopje, pp. 374 (in Macedonian)

12.Dimitrov, N. V., Metodijevski, D. (2017). Tourist valorization of urban tourism: The case of regional centres in Republic of Macedonia. International Scientifics Conference Geobalcanica 2017, Skopje, Republic of Macedonia, Proceedings.(in Macedonian) 